\title{
Principal component analysis for evaluating a ranking method used in the performance testing in sheep of Morada Nova breed
}

\section{Análise de componentes principais para avaliação de um método de classificação utilizado nos testes de desempenho em ovinos da raça Morada Nova}

\author{
Michelle Santos da Silva ${ }^{1 *}$; Luciana Shiotsuki ${ }^{2}$; \\ Raimundo Nonato Braga Lôbo²; Olivardo Facó
}

\begin{abstract}
A multivariate approach was adopted to evaluate the relationship among traits measured in the performance testing of Morada Nova sheep, verify the efficiency of a ranking method used in these tests and identify the most significant traits for use in future analyses. Data from 150 young rams participating in five versions of the performance tests for the Morada Nova breed were used. Twenty traits were measured in each animal: initial weight (IW), final weight (FW), average daily weight gain (ADG), loin eye area (LEA), scrotal circumference (SC), fat thickness (FT), conformation (C), precocity (Pc), muscularity (M), breed features (BF), legs (L), withers height (WH), chest width (CW), rump height (RH), rump width (RW), rump length (RL), body length (BL), body depth (BD), heart girth (HG) and body condition scoring (BCS). The Pearson's correlation coefficients ranged from -0.10 to 0.93 , with the highest correlations were between body weight variables and morphometric measurements. The three first principal components explained $72.28 \%$ of the total variability among all traits. The variables related to animal size defined the first principal component, whereas those related to visual appraisal and suitability for meat production defined the second and third principal components, respectively. The combination of traits from the principal component analysis showed that the ranking method currently used in the performance testing of Morada Nova sheep is efficient for selecting larger rams with better breed features and higher degrees of specialization for meat production.
\end{abstract}

Key words: Adaptability, meat sheep, selection, multivariate analysis, weighting

\section{Resumo}

Objetivou-se neste trabalho adotar uma abordagem multivariada para avaliar a relação entre as características medidas nos testes de desempenho de ovinos Morada Nova para verificar a eficácia do método de classificação utilizado nestes testes, e identificar as características mais importantes para serem usadas em análises futuras. Foram utilizados dados de 150 carneiros jovens participantes de cinco edições do teste de desempenho da raça Morada Nova. Vinte características foram mensuradas em cada animal: peso inicial (PI), peso final (PF), ganho de peso médio diário (GPMD), área de olho de lombo (AOL), perímetro escrotal (PE), espessura de gordura (EG), conformação $(\mathrm{C})$, precocidade $(\mathrm{Pc})$, musculosidade (M), tipo racial (TP), aprumos (A), altura de cernelha (AC), largura de peito (LP), altura da garupa (AG), largura da garupa (LG), comprimento da garupa (CG), comprimento corporal (CC), profundidade (P), perímetro torácico (PT) e escore de condição corporal (ECC). Os Coeficientes

1 Zootecnista, Discente de Mestrado do Programa do Programa de Pós-Graduação em Produção Animal UFERSA/UFRN, Universidade Federal Rural do Semiárido, UFERSA, Mossoró, RN, Brasil. E-mail: mig_871@hotmail.com

2 Pesquisadores, Empresa Brasileira de Pesquisa Agropecuária, EMBRAPA Caprinos e Ovinos, Sobral, CE, Brasil. E-mail: luciana.shiotsuki@embrapa.br; raimundo.lobo@embrapa.br; olivardo.faco@embrapa.br

* Author for correspondence 
de correlação de Pearson variaram de $-0,10$ a 0,93 , sendo que as maiores correlações foram entre as variáveis de peso corporal e medidas morfométricas. Os três primeiros componentes principais explicaram $72,28 \%$ da variabilidade total entre todas as variáveis. As variáveis relacionadas ao porte do animal obtiveram maiores ponderadores no primeiro componente principal, enquanto as características relacionadas à avaliação visual e aptidão para a produção de carne foram mais representativas no segundo e terceiro componentes principais, respectivamente. A combinação das variáveis formadas a partir da análise de componentes principais mostrou que, o método de classificação atualmente utilizado nos testes de desempenho de ovinos Morada Nova é eficiente para a seleção de carneiros maiores, com melhor padrão racial e maior grau de especialização para a produção de carne.

Palavras-chave: Adaptabilidade, ovinos de corte, seleção, análise multivariada, ponderação

\section{Introduction}

The sheep industry is a viable option for promoting rural development in Brazil because of the territorial area of this country and low labor costs of the sheep industry compared with other activities. Moreover, although the Brazilian flock presently numbers more than 17 million head (IBGE, 2013), current consumer demands for products of this species remain unmet. Therefore, the importance of this activity has increased, especially in the northeastern region, where sheep production plays a crucial role in regional development (COSTA et al., 2008).

In northeastern Brazil, locally adapted breeds and crossbred animals account for most of the sheep meat production. The hardiness and good adaptation of these genetic groups are strategic aspects for sheep farming in semiarid conditions. Moreover, these sheep provide substantial contributions to food security and reduce pressure on the environment and dependence on external food sources. These factors contribute to the increased profit margins of small producers (KOSGEY et al., 2006).

Morada Nova sheep is among the major breeds of hair sheep in northeast Brazil. The animals of this breed are of a small size, have high prolificacy (litter size) and are well adapted to the semi-arid climatic conditions and exploited for meat and skin production (FERNANDES et al., 2001). Even with these attributes, Morada Nova and many other locally adapted breeds have experienced a period of replacement by imported breeds considered of higher value by the majority of breeders. Thus, the awareness of certain breeders, researchers and educational institutions has influenced the development of certain activities used in the research and dissemination of information on breed traits. Among these activities, it is possible to highlight the use of centralized performance testing, which aims to identify potential young rams and promote breeds, and the breeders are highlighted (FACÓ et al., 2009).

Such performance testing uses a method of ranking the rams, and because many traits are used in this method, it is important to evaluate if combinations of traits are appropriate to efficiently rank the animals or if certain traits are redundant and unnecessary. Principal component analysis (PCA) is a method of multivariate analysis that evaluates the total variability of a great number of traits and eliminates the redundancy resulting from correlations among traits (HOTELLING, 1933; KHATTREE; DAYANAND, 2000).

The present study uses a PCA to evaluate the efficacy of the ranking method utilized in the centralized performance testing of Morada Nova sheep in reaching the objectives initially proposed by the breeders for selecting animals with faster growth rates and better carcasses without disregarding the breed standards. 


\section{Materials and Methods}

The data were from 150 young rams participating in five editions of centralized performance testing of Morada Nova breed by the Brazilian Association of Breeders of Morada Nova Sheep (ABMOVA) in partnership with the Brazilian Agricultural Research Corporation (Empresa Brasileira de Pesquisa Agropecuária) from 2008-2012 were used.

The animals were between 4 and 6 months old and weight ranging from 12 to $24 \mathrm{~kg}$. The performance tests were performed according to the methodology described by Facó et al. (2009) in which the following traits were evaluated:

- Body weight, measured at the beginning (initial weight; IW) and end (final weight; FW) of the test.

- Average daily weight gain (ADG), calculated as the ratio $\mathrm{ADG}=(\mathrm{FW}-\mathrm{IW}) /($ test duration $)$;

- Scrotal circumference (SC), measured at the end of the test;

- Visual scores (VS) composed for the conformation $(\mathrm{C})$, muscularity $(\mathrm{M})$, precocity $(\mathrm{Pc})$, breed features (BF) and legs (L), performed at the finish, with each trait scored on a scale of 1 to 6 , with 1 denoting inferior and 6 denoting excellent;

- The loin eye area (LEA) and fat thickness (FT) evaluated with Pie Medical Falco Vet ultrasound equipment (Pie Medical Imaging BV, Maastricht, the Netherlands) using a $180-\mathrm{mm}$ and $3.5-\mathrm{MHz}$ probe. These measurements were performed at the finish;

- Morphometric measurements of withers height (WH), chest width (CW), rump height $(\mathrm{RH})$, rump width (RW), rump length (RL), body length (BL), body depth (BD) and), heart girth (HG), evaluated with a ruler and measuring tape, and the body condition scoring (BCS), performed at the beginning and end of the tests, following a scale from 1 to 5 .
At the end of each test, the animals were ranked according to the performance score $(\mathrm{Sa})$ :

$\mathrm{Sa}=\mathrm{ADG}(40 \%)+\mathrm{LEA}_{\mathrm{p}}(15 \%)+\mathrm{SC}(10 \%)+$ FT $(10 \%)+$ BF $(15 \%)+$ C $(5 \%)+$ L $(5 \%)$;

The value of the LEA was weighed by the metabolic weight $\left(\right.$ LEAp $=$ LEA/Final Weight $\left.{ }^{0.75}\right)$ to allow better comparisons between lighter and heavier animals.

The animals were ranked according to four categories: elite (animals with Sa values higher than the average of Sa plus one standard deviation), superior (animals with Sa values from the average Sa up to the average plus one standard deviation), regular (animals with $\mathrm{Sa}$ values below the average down to the average minus one standard deviation) or inferior (animals with Sa values lower than the average minus one standard deviation).

Statistical analyses were performed with the procedures CORR and PRINCOMP of the Statistical Analysis System package (SAS $\left.{ }^{\circ}, 2002\right)$. The variables for PCA were standardized to a mean of zero and variance of one.

The number of principal components (PCs) that best simplified the variability in the data was selected by the criteria of Jolliffe (1972), which discards PCs with eigenvalues $<0.7$; of Kaiser (1960), which discards PCs with eigenvalues < 1.0; and of Cattell (1966), which uses a graphical scree plot for evaluating changes in the direction of the line that joins the eigenvalues of different components.

The nature of each selected PC was interpreted according to its traits, wherein the largest absolute weighting coefficient (eigenvector) was presented. Threshold values for an eigenvector used to determine its importance have not been described in the literature, and these values were interpreted according to relationships among the traits in the PCA. To correctly compare these PC traits, the effects of scale were removed, and the values were standardized according to the formula $\mathrm{T}_{\mathrm{s}}=(\mathrm{T}-\mu) / \sigma$, 
where $\mathrm{T}_{\mathrm{s}}$ is the standardized trait, $\mathrm{T}$ is the observed trait, $\mu$ is the average of the observations of the trait and $\sigma$ is the standard deviation of the observed trait.

The selected PCs were used as the score $\left(\mathrm{S}_{\mathrm{i}}\right)$ by summing the products of all $\mathrm{T}_{\mathrm{s}}$ by their respective eigenvectors $\left(a_{p}\right): S_{i}=\sum\left(T_{s .} a_{p}\right)$. Subsequently, Pearson's correlations between the performance testing score $(\mathrm{Sa})$ and $\mathrm{PC}$-derived scores $\left(\mathrm{S}_{\mathrm{i}}\right)$ were calculated. Finally, scatter graphs were plotted to score the $\mathrm{S}_{\mathrm{i}}$ of the young rams ranked in the elite and inferior categories according to their (Sa).

\section{Results and Discussion}

The means and coefficients of variation calculated for the evaluated traits (Table 1) were consistent with those reported in the literature for Morada Nova sheep (ARAÚJO FILHO et al., 2007; SILVA et al., 2007). As observed in Table 1, according to the coefficient of variation $(\mathrm{CV})$, there were two groups of traits. The first group consisted of traits measured in the body of the animal in centimeters with $\mathrm{CVs}<9 \%$, and the second group consisted of traits with $\mathrm{CVs}>17 \%$. Fat thickness was observed to be the variable of greatest instability.

Table 1. Descriptive analysis of the data structure, numbers of animals (N), means, standard deviations (SD) and coefficients of variation (CV\%) for the variables (V) evaluated during performance testing of Morada Nova sheep.

\begin{tabular}{lrrrr}
\hline \multicolumn{1}{c}{$\mathrm{V}^{1}$ (unit) } & $\mathrm{N}$ & MEAN & $\mathrm{SD}$ & CV (\%) \\
\hline IW $(\mathrm{kg})$ & 150 & 18.3701 & 4.0053 & 21.8033 \\
FW (kg) & 150 & 31.7381 & 5.0905 & 16.0391 \\
ADG (kg) & 150 & 0.1691 & 0.0302 & 17.8542 \\
LEA (cm $\left.{ }^{2}\right)$ & 150 & 9.4596 & 2.0100 & 21.2481 \\
SC (cm) & 150 & 27.8187 & 2.3961 & 8.6134 \\
FT (mm) & 150 & 2.1430 & 0.5497 & 25.6491 \\
C (1-6 points) & 150 & 3.3356 & 0.6827 & 20.4670 \\
Pc (1-6 points) & 150 & 3.3100 & 0.7256 & 21.9212 \\
M (1-6 points) & 150 & 3.1756 & 0.6730 & 21.1934 \\
BF (1-6 points) & 150 & 3.3044 & 0.8130 & 24.6034 \\
L (1-6 points) & 150 & 3.3678 & 0.5931 & 17.6097 \\
WH (cm) & 150 & 62.3853 & 3.4721 & 5.5656 \\
CW (cm) & 150 & 17.5453 & 1.4876 & 8.4784 \\
RH (cm) & 150 & 64.3840 & 2.9395 & 4.5656 \\
RW (cm) & 13.8493 & 1.0845 & 7.8305 \\
RL (cm) & 150 & 19.4493 & 1.3590 & 6.9875 \\
BL (cm) & 150 & 60.8193 & 3.2682 & 5.3737 \\
BD (cm) & 150 & 26.9487 & 1.5701 & 5.8262 \\
HG (cm) & 150 & 73.6100 & 4.6814 & 6.3598 \\
BCS (1-5 points) & 150 & 3.6433 & 0.6714 & 18.4285 \\
\hline
\end{tabular}

${ }^{1} \mathrm{IW}$ : initial weight, FW: final weight, ADG: average daily weight gain, LEA: loin eye area, SC: scrotal circumference, FT: fat thickness, C: conformation, Pc: precocity, M: muscularity, BF: breed features, L: legs, WH: withers height, CW: chest width, RH: rump height, RW: rump width, RL: rump length, BL: body length, BD: body depth, HG: heart girth and BCS: body condition scoring.

Pearson's correlations between the evaluated traits ranged from -0.10 to 0.93 (Table 2). The growth traits were correlated positively with morphometric traits, and several authors have found strong correlations between body weight and various morphometric traits, such as heart girth, abdominal perimeter, withers height, rump height and body length (VARADE et al., 1997; TEIXEIRA et al., 2000). Consequently, larger animals were also heavier. These associations allow certain body 
measurements to be used as indicators of animal growth and development (ARAÚJO FILHO et al., 2007; PINHEIRO; JORGE, 2010).

Average daily weight gain presented low to moderate correlations with all traits. Here, it is important to emphasize the low correlation between initial weight and average daily weight gain, which suggests that the initial weight of lambs in performance testing presented limited interference with weight gain. However, there was a high correlation between initial weight and final weight.

The body condition scoring showed close null correlations with the visual scores (conformation, precocity, muscularity, breed features and legs), which is inconsistent with the report by Esteves et al. (2010), who observed that animals with better body condition also had better conformation. However, conformation was evaluated relatively comprehensively in the Morada Nova performance testing, which can explain this difference. The animals were evaluated by three judges who independently compared the evaluated animal with an ideal animal based on size, bone and muscle structure, balance junctions among the animal parts etc.

The visual scores for breed features and legs presented correlations with other traits that were close to null. However, the correlations among the five traits that were visually scored were from moderate to high. Importantly, breed features, which is regarded as the most important trait by breeders, was not correlated with other traits of recognized economic and zootechnical importance, such as average daily weight gain, loin eye area, scrotal circumference and fat thickness.

The correlations of loin eye area and fat thickness with the other traits were moderate except with breed features and legs. The first traits were highly important and indicate muscularity, fat deposition degree and carcass finishing.

The PCA generated 20 components, and the first five would be selected by the Jolliffe criterion (1972) and accounted for $80.22 \%$ of the total variation in this dataset (Table 3). Notably, the total variation depends on the number and type of variables included in the analysis and how they were correlated.

Using the criterion of the scree plot (CATTELL, 1966), the identification of the inflection point determines the importance of each principal components. The difference between the eigenvalues becomes increasingly smaller, especially after the inflection point, which occurred after the third principal components in this study (Figure 1). For this criterion, it was possible to explain $72.28 \%$ of the total variance by considering the first three components. This criterion is fairly subjective with respect to the identification of the inflection point. For this study, this method was used to reinforce the criterion based on variance (KAISER, 1960), whereby eigenvalues $\geq 1$ are considered. Therefore, the first three principal components were selected, as observed in Table 3. 


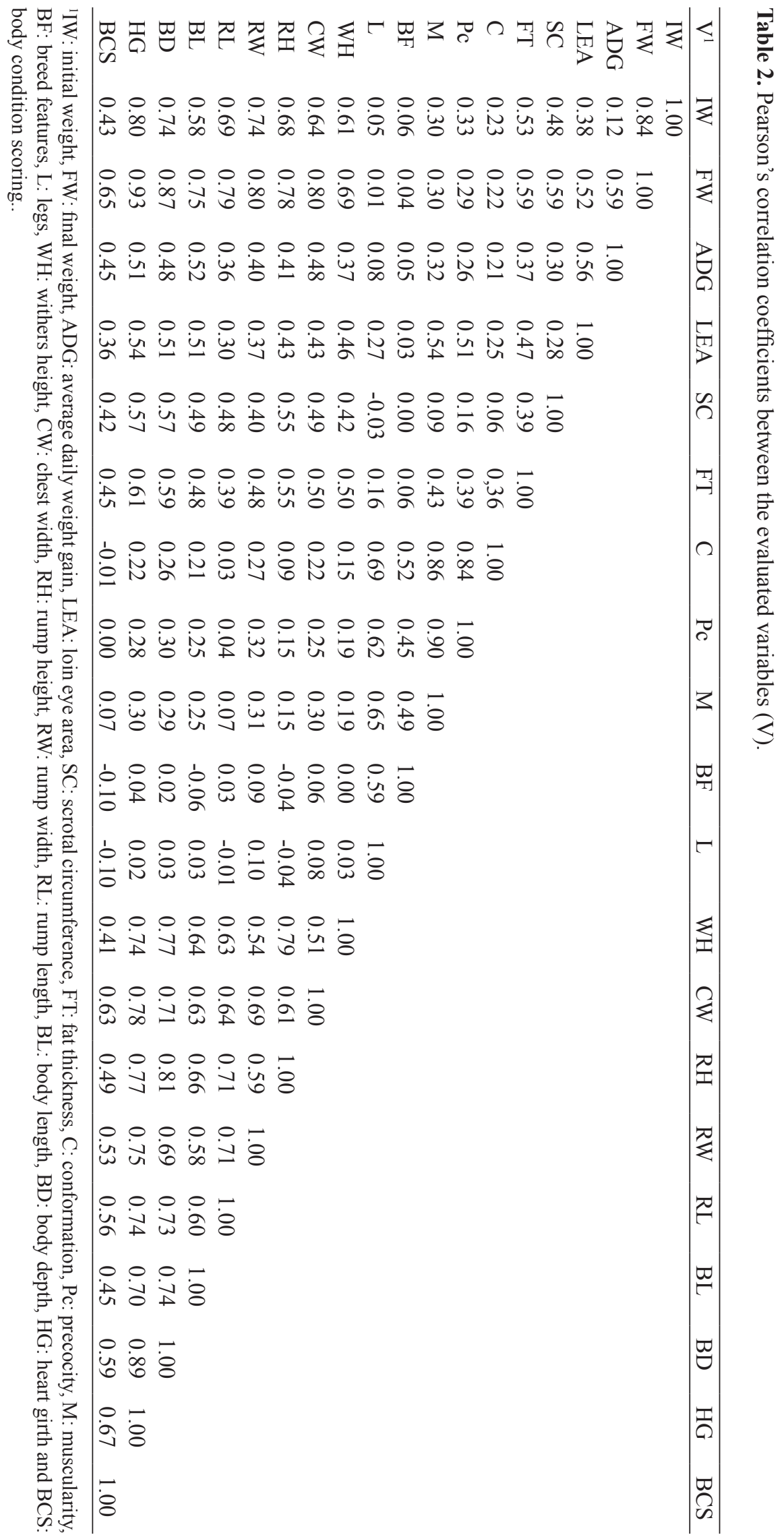


Table 3. Principal components (PCs), eigenvalues, percentages of variance described by the components (VPC), and cumulative percentages of variance described by the components $\left(\mathrm{VPC}_{\mathrm{C}}\right)$ of the characteristics evaluated in Morada Nova sheep.

\begin{tabular}{lccc}
\hline PCs & Eigenvalue & VPC $(\%)$ & VPC $_{C}(\%)$ \\
\hline PC1 & 9.6623 & 48.3117 & 48.31 \\
PC2 & 3.6262 & 18.1311 & 66.44 \\
PC3 & 1.1679 & 5.8395 & 72.28 \\
PC4 & 0.8652 & 4.3262 & 76.61 \\
PC5 & 0.7219 & 3.6096 & 80.22 \\
PC6 & 0.6693 & 3.3467 & 83.56 \\
PC7 & 0.5599 & 2.7994 & 86.36 \\
PC8 & 0.4457 & 2.2283 & 88.59 \\
PC9 & 0.3898 & 1.9491 & 90.54 \\
PC10 & 0.3385 & 1.6927 & 92.23 \\
PC11 & 1.5538 & 93.79 \\
PC12 & 0.3108 & 1.3317 & 95.12 \\
PC13 & 0.2663 & 1.0995 & 96.22 \\
PC14 & 0.2199 & 0.8925 & 97.11 \\
PC15 & 0.1785 & 0.8524 & 97.96 \\
PC16 & 0.1705 & 0.7393 & 98.70 \\
PC17 & 0.1479 & 0.5772 & 99.28 \\
PC18 & 0.1154 & 0.3777 & 99.66 \\
PC19 & 0.0755 & 0.3042 & 99.96 \\
PC20 & 0.0608 & 0.0375 & 100.00 \\
\hline
\end{tabular}

Figure 1. Scree plot of the eigenvalues that correspond to each of the 20 principal components.

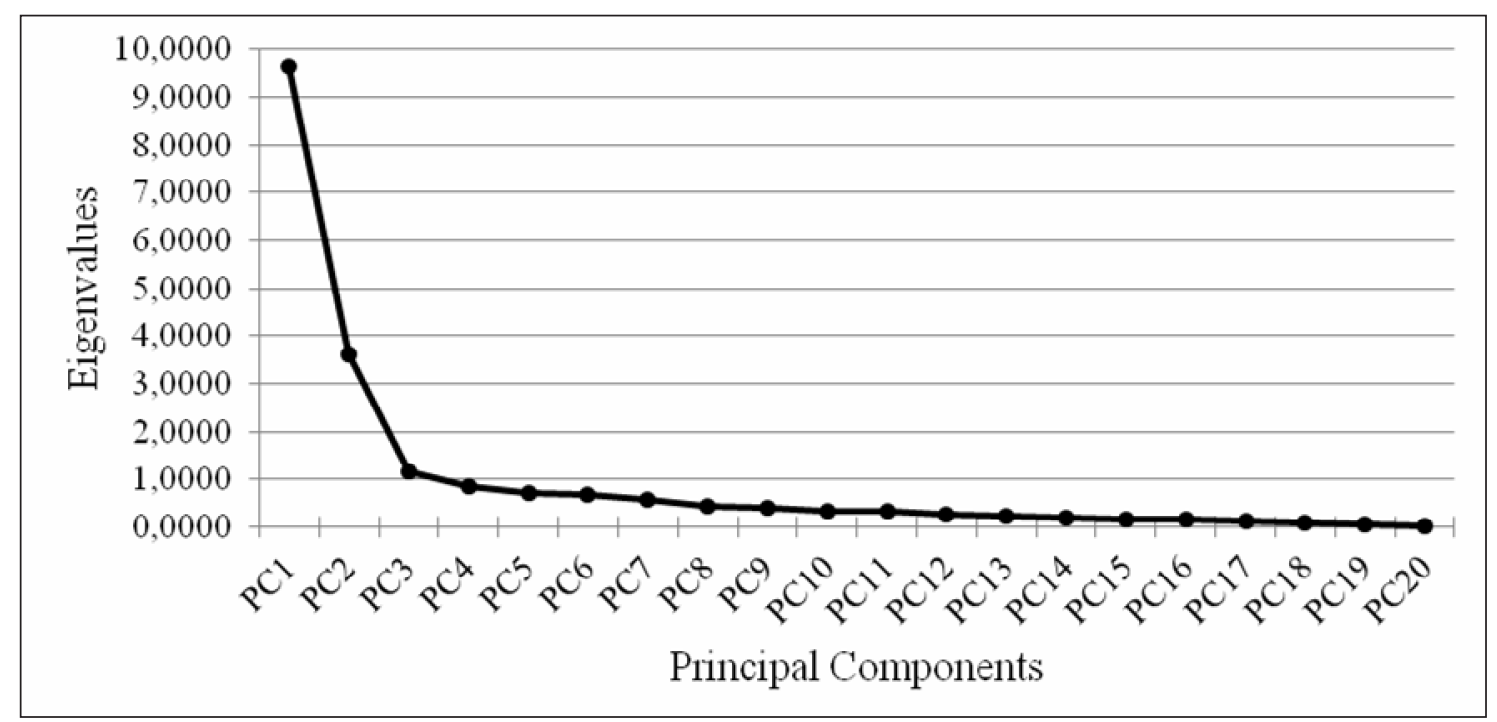


Although it is possible to justify the need for a greater number of Using the criterion of the scree plot (CATTELL, 1966), the identification of the inflection point determines the importance of each principal components because of the complex relationships between the 20 studied traits, up to three components were included because of the low interpretability and additional variability observed after the third component.
The traits of the first component (PC1) with higher weighting coefficients (eigenvectors) were final weight, heart girth and body depth (Table 4). In general, the morphometric variables also had high weighting coefficients $(>0.24)$, indicating that the ranking of animals based on a possible score formed from this component would result in the selection of animals by frame size.

Table 4. Weighting coefficients of the principal components retained for the characteristics, ranked in order of greater importance.

\begin{tabular}{cccc}
\hline $\mathrm{V}^{1}$ & PC1 & PC2 & PC3 \\
\hline IW & 0.2604 & -0.0455 & $\mathbf{0 . 3 7 9 8}$ \\
FW & $\mathbf{0 . 3 0 6 4}$ & -0.0816 & 0.0294 \\
ADG & 0.1873 & 0.0294 & $\mathbf{- 0 . 5 8 9 1}$ \\
LEA & 0.2048 & 0.1470 & $\mathbf{- 0 . 4 4 9 0}$ \\
SC & 0.1963 & -0.1003 & 0.0591 \\
FT & 0.2229 & 0.0736 & -0.0846 \\
C & 0.1178 & $\mathbf{0 . 4 4 1 5}$ & 0.0432 \\
Pc & 0.1403 & $\mathbf{0 . 4 2 4 7}$ & -0.0356 \\
M & 0.1448 & $\mathbf{0 . 4 3 5 5}$ & -0.0819 \\
BF & 0.0349 & $\mathbf{0 . 3 4 1 2}$ & $\mathbf{0 . 3 4 8 9}$ \\
L & 0.0508 & $\mathbf{0 . 4 2 7 0}$ & 0.1317 \\
WH & 0.2466 & -0.0832 & 0.0556 \\
CW & 0.2624 & -0.0463 & 0.0106 \\
RH & 0.2641 & -0.1326 & 0.0677 \\
RW & 0.2590 & -0.0274 & 0.1817 \\
RL & 0.2489 & -0.1580 & 0.2358 \\
BL & 0.2546 & -0.0598 & -0.1412 \\
BD & $\mathbf{0 . 2 9 4 4}$ & -0.0665 & 0.0461 \\
HG & $\mathbf{0 . 3 0 1 5}$ & -0.0744 & 0.0370 \\
BCS & 0.2097 & -0.1543 & -0.1639 \\
\hline
\end{tabular}

${ }^{1}$ IW: initial weight, FW: final weight, ADG: average daily weight gain, LEA: loin eye area, SC: scrotal circumference, FT: fat thickness, C: conformation, Pc: precocity, M: muscularity, BF: breed features, L: legs, WH: withers height, CW: chest width, RH: rump height, RW: rump width, RL: rump length, BL: body length, BD: body depth, HG: heart girthand BCS: body condition scoring.

For the second component (PC2), the traits related to visual scores had higher weighting coefficients (conformation, muscularity, body depth, precocity and breed features). Thus, the ranking of lambs according to an index formed from the weightings in this component would lead to the selection of animals according to aptitude and breed standards.
There was a contrast in the third component (PC3), with the average daily weight gain and loin eye area traits presenting higher and negative eigenvectors and the breed features and initial weight traits presenting higher and positive eigenvectors. The contrast between breed features and traits related to meat-producing ability, such 
as average daily weight gain and loin eye area, appears to indicate that Morada Nova sheep show little specialization for meat production, which was previously observed by Fernandes Júnior et al. (2013). This result was somewhat expected because Morada Nova is a relatively recent Brazilian locally adapted breed. Therefore, the ranking of animals according to score formed from the weightings contained in PC3 would lead to the selection of animals according to their degree of specialization for meat production.

In general, the three selected components showed that the most important traits according to the highest weighting coefficient values were final weight, heart girth, body depth, conformation, muscularity, legs, precocity, breed features, average daily weight gain, loin eye area and initial weight.

All of the measured body weights were important to the analysis because their weighting coefficients were high in one of the three components. In performance testing of rams, greater emphasis is generally given to live weight because it is the principal indicator of animal growth (BATHAEI; LEROY, 1996).

Heart girth and body depth had higher weightings among the morphometric traits that are indicators of body mass. The morphometric traits usually mentioned in the literature regarding weight prediction are heart girth, body length, withers height and rump height (KHALIL; VACCARO, 2002; AFOLAYAN et al., 2006; SOWANDE; SOBOLA, 2008). However, doubts remain in the selection of the best trait used for such predictions. In most studies of sheep, heart girth is the most widely used measure and is considered the most suitable and reliable for estimating live weight (THIRUVENKADAN, 2005; SILVA et al., 2006; PESMEN; YARDIMCI, 2008; YILMAZ et al., 2012). In this study, the trait with the highest correlation with final weight was heart girth (Table 2).

All of the visual scores were considered important for the selected principal components, although studies have shown that the traits evaluated by these scores are partly controlled by the same set of genes. Therefore, the selection of one of these traits will result in a correlated response to the other traits (SOMAVILLA et al., 2012). Regarding sheep bred for meat, conformation is the most common evaluation performed on farms (NSOSO et al., 2000; WEBER et al., 2009), and this was the visual trait with the highest weighting in this study. This measurement serves as an indicator of carcass components and is better evaluated when the appraiser an better visualize the body parts of the animal that present greater commercial value for meat production, including the loin eye area and legs (OLIVEIRA et al., 2002). However, it is important consider the distinct methods by which this trait is evaluated.

The loin eye area also had a considerable eigenvector, and studies have shown that this trait is considered a good indicator of body composition and muscularity; therefore, a greater loin eye area value indicates a greater yield of sellable carcass cuts (COSTA et al., 2012).

The traits that did not have high weighting coefficients in any of the first three components were scrotal circumference, fat thickness, withers height, chest width, rump height, rump width, rump length, body length and body condition scoring. The vast majority of variables with smaller weightings were morphometric measurements, which was most likely caused by the high correlations amongst those traits. However, this result does not mean that these traits are unimportant for assessments of zootechnical indices. The reduction in the set of variables according to the PCA suggests that body measurements can be simplified to several traits. This aspect is important in reducing the time and cost required for measurements.

Although scrotal circumference is used as a selection criterion to indicate fertility in females and reproductive capacity in males (PEÑA et al., 2000; DIAS et al., 2003), this trait was not 
important for the PCA applied here, although significant correlations were likely maintained with the morphometric traits. Fat thickness did not show high weighting coefficients in the third principal component selected, although it is associated with the qualitative attributes of carcass, carcass yield and finishing precocity (CARTAXO et al., 2011). The scores built from the three components presented low but significant correlations with the scores used to rank the rams in the performance tests (Sa). These correlations were $0.3342,-0.3405$ and 0.2340 for S1, S2 and S3, respectively. These low correlations were somewhat expected because Sa evaluates the overall performance of the young rams by seeking a balance between the growth rate, body structure and breed aspects without selecting for a specific direction. However, each principal components tends to evaluate a specific aspect (S1, frame size; S2, animal type and breed standards; and S3, specialization for meat production).

There was a noticeable separation between animals classified as elite or inferior by the ranking method $(\mathrm{Sa})$ when evaluating the first two components (Figure 2A), and the separation was determined mainly by the first component (horizontal axis). Therefore, smaller animals tended to be classified as inferior and larger animals tended to be classified as elite in the performance testing. The second component (S2) presented a lower capacity for classifying animals as elite or inferior, although it was possible to perceive a tendency of animals classified as inferior to show negative
S2 values (Figures $2 \mathrm{~A}$ and $2 \mathrm{~B}$ ). Thus, the rams with lower visual appraisal scores (conformation, muscularity, precocity, breed features and legs) tended to be classified as Inferior, although certain animals with both positive and negative visual scores were classified as elite.

The perfect separation of elite and inferior animals could not be ensured by the score built from the third PC (S3), although most animals classified as Inferior showed positive values for S3, whereas most animals classified as elite had negative values for S3 (Figures 2B and 2C). Therefore, animals with less specialization for meat production tended to be classified as Inferior, whereas animals with a higher degree of specialization tended to be classified as elite.

The results of this study indicate that the ranking method utilized in the centralized performance tests of Morada Nova sheep (Sa) tend to select larger animals with better types and greater degrees of meat production specialization, although such selections may not be the optimal because the weighting coefficients were not derived from economic values. However, clearly contrasting traits (average daily weight gain and loin eye area $\mathrm{x}$ breed features) in the Sa reduce its effectiveness for promoting rapid population changes, and aspects of the Morada Nova breed and socioeconomic and environmental conditions of the production systems in which this breed is used may indicate that slower changes are the most desirable. 
Figure 2. Distributions of animals classified as Elite or Inferior by the rating index (Sa) used during the performance testing of Morada Nova sheep, according to indices formed from the first 3 principal components (S1, S2 and S3).

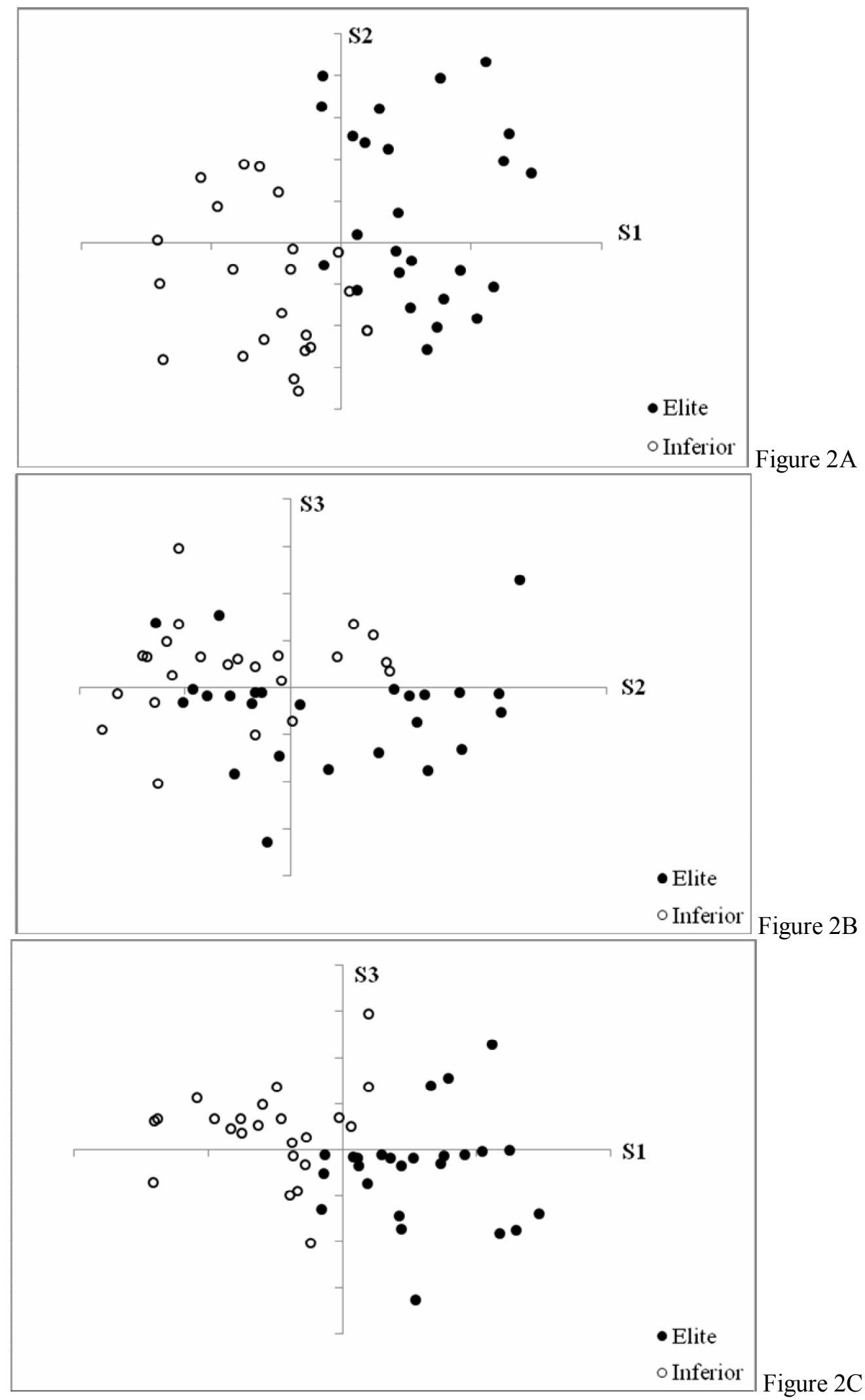




\section{Conclusion}

The ranking method currently used for young rams that participate in centralized performance testing of Morada Nova sheep is efficient and complies with the initially proposed goals for selecting animals with faster growth rates and better carcasses without disregarding breed standards. The PCA performed here was efficient and demonstrated that a smaller number of traits may be considered once they are grouped according to type so that they maintain high correlations with each other.

\section{Acknowledgments}

The authors acknowledge the financial support from the National Council for Scientific and Technological Development (CNPq, 135447/2011.9) and the Embrapa Goats and Sheep and Brazilian Association of Breeders of Morada Nova Sheep for providing the data used in the study.

\section{References}

AFOLAYAN, R. A.; ADEYINKA, I. A.; LAKPINI, C. A. M. The estimation of live weight from body measurements in Yankasa sheep. Czech Journal of Animal Science, Praga, v. 51, n. 8, p. 343-348, 2006.

ARAÚJO FILHO, J. T.; COSTA, R. G.; FRAGA, A. B.; SOUSA, W. H.; GONZAGA NETO, S.; BATISTA, A. S. M.; CUNHA, M. G. G. Efeito de dieta e genótipo sobre medidas morfométricas e não constituintes da carcaça de cordeiros deslanados terminados em confinamento. Revista Brasileira de Saúde e Produção Animal, Salvador, v. 8, n. 4, p. 394-404, 2007.

BATHAEI, S. S.; LEROY, P. L. Growth and mature weight of Mehraban fat-tailed sheep. Small Ruminant Research, Amsterdam, v. 22, n. 2, p. 155-162, 1996.

CARTAXO, F. Q.; SOUSA, W. H.; CEZAR, M. F.; COSTA, R. G.; CUNHA, M. D. G. G.; GONZAGA NETO, S. Características de carcaça determinadas por ultrassonografia em tempo real e pós-abate de cordeiros terminados em confinamento com diferentes níveis de energia na dieta. Revista Brasileira de Zootecnia, Viçosa, v. 40, n. 1, p. 160-167, 2011.
CATTELL, R. B. The scree test for the number of factors. Multivariate Behavioral Research, Illinois, v. 1, n. 2, p. 245-276, 1966.

COSTA, R. G.; ALMEIDA, C. C.; PIMENTA FILHO, E. C.; HOLANDA JUNIOR, E. V.; SANTOS, E. N. M. Caracterização do sistema de produção caprino e ovino na região semi-árida do estado da Paraíba, Brasil. Archivos de Zootecnia, Córdoba, v. 57, n. 218, p. 195-205, 2008.

COSTA, R. G.; LIMA, A. G. V.O.; OLIVEIRA, C. F. S.; AZEVEDO, P. S.; MEDEIROS, A. N. Utilização de diferentes metodologias para determinação da área de olho de lombo em ovinos. Archivos de Zootecnia, Córdoba, v. 61, n. 236, p. 615-618, 2012.

DIAS, L. T.; EL FARO, L.; ALBUQUERQUE, L. G. Estimativas de herdabilidade para perímetro escrotal de animais da raça Nelore. Revista Brasileira de Zootecnia, Viçosa, v. 32, n. 6, p. 1878-1882, 2003.

ESTEVES, R. M. G.; OSÓRIO, J. C. S.; OSÓRIO, M. T. M.; MENDONÇA, G.; OLIVEIRA, M. M.; WIEGAND, M.; VILANOVA, M. S.; CORREA, F.; JARDIM, R. D. Avaliação in vivo e da carcaça e fatores determinantes para o entendimento da cadeia da carne ovina. Current Agricultural Science and Technology, Pelotas, v. 16, n. 1-4, p. 101-108, 2010.

FACÓ, O.; LÔBO, R. N. B.; BOMFIM, M. A. D.; LIMA JÚNIOR, F. E. B.; SILVA, D. C. C.; NOBRE, J. A. Teste de desempenho individual de reprodutores da raça Morada Nova: resultados da prova em Morada Nova CE - 18/02 a 04/06/2008. Sobral: Embrapa Caprinos e Ovinos, 2009. 30 p. (Série Documentos, n. 91).

FERNANDES, A. A. O.; BUCHANAN, D.; SELAIVEVILLAROEL, A. B. Avaliação dos fatores ambientais no desenvolvimento corporal de cordeiros desmamados da raça Morada Nova. Revista Brasileira de Zootecnia, Viçosa, v. 30, n. 5, p. 1460-1465, 2001.

FERNANDES JÚNIOR, G. A.; LÔBO, R. N. B.; MADRUGA, M. S.; LÔBO, A. M. B. O.; VIEIRA L. S.; FACÓ, O. Genotype effect on carcass and meat quality of lambs finished in irrigated pastures in the semiarid Northeastern Brazil. Arquivo Brasileiro de Medicina Veterinária e Zootecnia, Belo Horizonte, v. 65, n. 4, p. 1208-1216, 2013.

HOTELLING, H. Analysis of a complex of statistical variables into principal components. Journal of Educational Psychology, Washington, v. 24, n. 6, p. 417441, 1933.

INSTITUTO BRASILEIRO DE GEOGRAFIA E ESTATÍSTICA - IBGE. Pesquisa pecuária municipal. Efetivo dos rebanhos. Brasília: IBGE, 2013. Available at: 
$<$ http://www.sidra.ibge.gov.br/bda/pecua/default.asp?t= $2 \& \mathrm{z}=\mathrm{t} \& \mathrm{o}=24 \& \mathrm{u} 1=1 \& \mathrm{u} 2=1 \& \mathrm{u} 3=1 \& \mathrm{u} 4=1 \& \mathrm{u} 5=1 \& \mathrm{u} 6=1$ $\& u 7=1>$. Accessed at: 27 apr. 2015.

JOLLIFFE, I. T. Discarding variables in a principal component analysis. I: Artificial data. Applied Statistics, Malden, v. 21, n. 2, p. 160-173, 1972.

KAISER, H. F. The application of electronic computers to factor analysis. Educational and Psychological Measurement, Thousand Oaks, v. 20, n. 1, p. 141-151, 1960.

KHALIL, R.; VACCARO, L. Peso y mediciones corporales en vacas de doble propósito: su interrelación y asociación con valor genético para tres características productivas. Zootecnia Tropical, Maracay, v. 20, n. 1, p. 11-30, 2002.

KHATTREE, R.; DAYANAND, N. N. Multivariate data reduction and discrimination with SAS Software. Cary: NC: SAS Institute Inc, 2000. 571 p.

KOSGEY, I. S.; BAKER, R. L.; UDO, H. M. J.; VAN ARENDONK, J. A. M. Successes and failures of small ruminant breeding programmes in the tropics: a review. Small Ruminant Research, Amsterdam, v. 61, n. 1, p. 1328, 2006.

NSOSO, S. J.; YOUNG, M. J.; BEATSON, P. R. A review of carcass conformation in sheep: assessment, genetic control and development. Small Ruminant Research, Amsterdam, v. 35, n. 2, p. 89-96, 2000.

OLIVEIRA, M. V. M.; PÉREZ, J. R. O.; ALVES, E. L; MARTINS, A. R. V.; LANA, R. P. Avaliação da composição de cortes comerciais componentes corporais e órgãos internos de cordeiros confinados e alimentados com dejetos de suínos. Revista Brasileira de Zootecnia, Viçosa, v. 31, n. 3, p. 1459-1468, 2002.

PEÑA, C. D. O.; QUEIROZ, S. A. de; FRIES, L. A. Estimação de fatores de correção do perímetro escrotal para idade e peso corporal em touros jovens da raça Nelore1. Revista Brasileira de Zootecnia, Viçosa, v. 29, n. 6, p. 1667-1675, 2000.

PESMEN, G.; YARDIMCI, M. Estimating the live weight using some body measurements in Saanen goats. Archiva Zootechnica, Bucaresti, v. 11, n. 4, p. 30-40, 2008.

PINHEIRO, R. S. B.; JORGE, A. M. Medidas biométricas obtidas in vivo e na carcaça de ovelhas de descarte em diferentes estágios fisiológicos. Revista Brasileira de Zootecnia, Viçosa, v. 39, n. 2, p. 440-4545, 2010.
SILVA, D. C.; AZEVÊDO, D. M. M. R.; ALVES, A. A.; CAMPELO, J. E. G.; OLIVEIRA, M. E.; MALHADO, C. H. M. Estimativa do peso vivo através do perímetro torácico de ovinos Santa Inês. Revista Científica de Produção Animal, Teresina, v. 8, n. 2, p. 41-46, 2006.

SILVA, N. V.; FRAGA, A. B.; ARAÚJO FILHO, J. T.; CAVALCANTI NETO, C.; SILVA, F. L.; COSTA, P. P. S.; LIRA JÚNIOR, W. B. Caracterização morfométrica de ovinos deslanados Cabugi e Morada Nova. Revista Científica de Produção Animal, Teresina, v. 9, n. 1, p. 65-75, 2007.

SOMAVILLA, A. L.; DIAS, L. T.; TEIXEIRA, R. D. A. Environmental and genetic effects on conformation, precocity and musculature traits at weaning in Suffolk lambs. Small Ruminant Research, Amsterdam, v. 102, n. 2, p. 131-134, 2012.

SOWANDE, O. S.; SOBOLA, O. S. Body measurements of west African dwarf sheep as parameters for estimation of live weight. Tropical Animal Health and Production, Edinburgh, v. 40, n. 6, p. 433-439, 2008.

SAS. SAS Software. Version 9.1. Cary, North Carolina: SAS Institute Inc., 2002.

TEIXEIRA, M. P. B.; BARROS, N. N.; ARAÚJO, A. M. de; SELAIVE-VILLAROEL, A. B. Relação entre medidas corporais e peso vivo em caprinos das Raças Saanen e Anglo-Nubiana. Revista Científica de Produção Animal, Teresina, v. 2, n. 2, p. 178-189, 2000.

THIRUVENKADAN, A. K. Determination of best-fitted regression model for estimation of body weight in Kanni Adu kids under farmer's management system. Livestock Research for Rural Development, Cali, Colombia, v. 17, n. 7, p. 1-11, 2005.

VARADE, P. K.; ALI, S. Z.; MALKHEDE, P. S. Body measurements of local goats under field conditions. Indian Veterinary Journal, Madras, v. 74, n. 5, p. 448449, 1997.

WEBER, T.; RORATO, P. R. N.; LOPES, J. S.; COMIN, J. G.; DORNELLES, M. A.; ARAÚJO, R. O. Parâmetros genéticos e tendências genéticas e fenotípicas para características produtivas e de conformação na fase prédesmama em uma população da raça Aberdeen Angus. Revista Brasileira de Zootecnia, Viçosa, v. 38, n. 5, p. 832-842, 2009.

YILMAZ, O.; CEMAL, I.; KARACA, O. Estimation of mature live weight using some body measurements in Karya sheep. Tropical Animal Health and Production, Edinburgh, v. 45, n. 2, p. 397-403, 2012. 
